\title{
Clinico-etiological study of pediatric dermatoses in tertiary health care hospital in East-coast Andhra Pradesh, India
}

\author{
Indira Bonthu, Suruthi Purushothaman*, Nivedita Devi Vukkadala
}

Department of Dermatology, Venereology, Leprology, Rangaraya Medical College, Kakinada, Andhra Pradesh, India

Received: 16 March 2020

Revised: 29 April 2020

Accepted: 30 April 2020

\section{*Correspondence:}

Dr. Suruthi Purushothaman,

E-mail: surupgsa@gmail.com

Copyright: ( $)$ the author(s), publisher and licensee Medip Academy. This is an open-access article distributed under the terms of the Creative Commons Attribution Non-Commercial License, which permits unrestricted non-commercial use, distribution, and reproduction in any medium, provided the original work is properly cited.

\begin{abstract}
Background: Pediatric dermatoses vary vastly from adult dermatoses in clinical presentation, treatment and prognosis and are more influenced by socioeconomic status, climatic exposure, dietary habits, external environment, thereby needing a special view in this field. The present study was carried to determine the clinico-epidemiological patterns of pediatric dermatoses.

Methods: Consecutive 2581 children aged >1 month to 12 years with 2661 dermatoses attending dermatology OPD in tertiary care hospital, Kakinada (May 2018 to June 2019) with clinical evidence of cutaneous disorder were studied. Complete history and cutaneous examination with necessary investigations are recorded.

Results: Infestations disorder in $39.68 \%$ followed by eczematous disorder $19.80 \%$, infection in $13.71 \%$, pigmentary disorder in $8.34 \%$, papulosquamous disorder in $5.82 \%$, appendageal disorder in $2.93 \%$, nutritional disorder in $2.21 \%$ and drug reactions including toxic epidermal necrolysis in $1.12 \%$, child abuse and sexually transmitted diseases in $0.37 \%$ was the pattern in the present study. Rare cases including aplasia cutis, cutis laxa, ectodermal dysplasia, monilethrix and griscelli syndrome, epidermolysis bullosa, ichthyosis, palmoplantar keratoderma and congenital syphilis were also observed. The most common cutaneous dermatoses are infection and infestations followed by eczemas and nutritional disorders. Surprisingly STD and child abuse contributed significantly which cannot be neglected. Genodermatosis were notable in the study probably due to the high incidences of consanguineous marriage Conclusions: The study reinforces features of tropical paediatric dermatology especially high prevalence of infections and infestations in school children (5-12 years) which highlights the need of proper counselling of caretaker regarding skin hygiene and establishment of specialized paediatric dermatology clinics.
\end{abstract}

Keywords: Children, Genodermatosis, Infections, Paediatric dermatoses, South India

\section{INTRODUCTION}

Dermatoses in children vary vastly from adult dermatoses in clinical presentation, treatment, and prognosis and are more influenced by socioeconomic status, climatic exposure, dietary habits, external environment, thereby needing a special view in this field. ${ }^{1}$

Evaluation of cutaneous disorder forms a very essential component of primary health care practices specially in children from which health status and personal hygiene of the community can be indirectly judged. ${ }^{2}$

Cutaneous diseases among children constitutes $30 \%$ of visits to a dermatologists. ${ }^{3}$ Based on school surveys it has been estimated that the prevalence of pediatric dermatoses in various parts of India has ranged from $8.71 \%$ to $35 \%$ with pyoderma and malnutrition being more prevalent in developing countries, while eczemas are more common in developed countries. ${ }^{4}$ Immature 
immune system and increased exposure to sub clinical infectious carriers in school and family environment makes this age group population more susceptible to cutaneous dermatoses especially infections and infestations. $^{5}$

The present study was carried to determine the clinicoepidemiological patterns of common pediatric dermatoses presenting to a tertiary health care centre, coastal Southern India.

\section{METHODS}

This study was conducted in the dermatology, venereology, leprology (DVL) department of the tertiary health care centre in coastal South India after obtaining approval from institutional ethics committee.

This region is a typical tropical area with high temperature and humidity and is referred to as one of the green belts of South India.

All children ageing $>1$ month to 12 years, attending the DVL out-patient department (OPD) with any dermatoses between the period of May 2018 and June 2019 were enrolled in the study. The diagnosis was made by a dermatologist based on detailed history, cutaneous examination and appropriate hematological and biochemical investigations, VDRL test, $\mathrm{KOH}$ examination, Gram's stained smear, Tzanck test and skin biopsy etc. The diseases were tabulated based on the etiology and results were analyzed.

\section{RESULTS}

During the study period of one year, 27,854 new cases attended this study DVL OPD. Among them a total of 2581 children with 2661 cutaneous dermatoses were seen, thus constituting $9.5 \%$.

Among these children, $80(3 \%)$ had more than one dermatosis. Total boys were $1570(60.83 \%)$ and girls were $1011(39.17 \%)$ with boy to girl ratio 1.5:1.

Infants ( 2 months to 12 months) were 390 (15.11\%) with 204 boys and 186 girls.

Preschool group children (>1 year to 6 years) were 989 constituting $38.32 \%$ with 652 boys and 337 girls.

School children (7 to 12 years) were the largest group in this study constituting 1202 (46.58\%) children with 714 boys and 488 girls.

Overall, in this study, $>1$ month to 12 years age group most common type of dermatoses was infestations disorder in 1056 children contributing $39.68 \%$ followed by eczematous disorder in 527 children (19.80\%), infection in 365 children $(13.71 \%)$, pigmentary disorder in 222 children $(8.34 \%$ ), papulosquamous disorder in 155 children $(5.82 \%)$, appendageal disorder in 78 children $(2.93 \%)$, nutritional disorder in 59 children $(2.21 \%)$ and drug reactions in 30 children $(1.12 \%)$.

Among infestations scabies was the most common in all the age group contributing $51.89 \%$ (Table 1).

Table 1: Distribution of study population with infections and infestations according to their individual etiology.

\begin{tabular}{|c|c|c|c|c|c|c|c|}
\hline Category & \multicolumn{2}{|c|}{ Sub category } & $\begin{array}{l}2-12 \\
\text { months }\end{array}$ & $\begin{array}{l}2-6 \\
\text { years }\end{array}$ & $\begin{array}{l}\text {-12 } \\
\text { years }\end{array}$ & Total & Percentage \\
\hline \multirow{3}{*}{ Infestations } & \multicolumn{2}{|l|}{ Scabies } & 68 & 224 & 256 & 548 & 20.59 \\
\hline & \multicolumn{2}{|c|}{ Pediculosis } & 54 & 153 & 169 & 376 & 14.13 \\
\hline & \multicolumn{2}{|c|}{ Papular urticaria } & 34 & 47 & 51 & 132 & 4.96 \\
\hline \multirow{13}{*}{ Infections } & \multirow{5}{*}{ bacterial } & Impetigo & 22 & 58 & 22 & 102 & 3.83 \\
\hline & & Pyoderma & 10 & 34 & 16 & 60 & 2.25 \\
\hline & & Hansen's disease & 0 & 2 & 4 & 6 & 0.22 \\
\hline & & Congenital syphilis & 1 & 0 & 0 & 1 & 0.03 \\
\hline & & Lupus and cutaneous tuberculosis & 1 & 0 & 8 & 9 & 0.33 \\
\hline & \multirow{3}{*}{ Fungal } & Dermatophyte infections & 12 & 25 & 44 & 81 & 3.04 \\
\hline & & Cutaneous candidiasis & 4 & 1 & 1 & 6 & 0.22 \\
\hline & & Tinea versicolar & 5 & 5 & 18 & 28 & 1.05 \\
\hline & \multirow{5}{*}{ Viral } & Molluscum contagiosum & 0 & 8 & 10 & 18 & 0.67 \\
\hline & & Verruca vulgaris & 0 & 5 & 12 & 17 & 0.63 \\
\hline & & Varicella & 1 & 6 & 18 & 25 & 0.93 \\
\hline & & Herpes simplex & 0 & 2 & 3 & 5 & 0.18 \\
\hline & & Herpes zoster & 0 & 2 & 5 & 7 & 0.26 \\
\hline
\end{tabular}


Table 2: Distribution of study population with non-infectious dermatoses according to their individual etiology.

\begin{tabular}{|c|c|c|c|c|c|c|c|}
\hline Category & \multicolumn{2}{|c|}{ Sub category } & $\begin{array}{l}\text { 2-12 } \\
\text { months }\end{array}$ & $\begin{array}{l}2-6 \\
\text { years }\end{array}$ & $\begin{array}{l}7-12 \\
\text { years }\end{array}$ & Total & Percentage \\
\hline \multirow{6}{*}{$\begin{array}{l}\text { Dermatitis } \\
\text { disorder }\end{array}$} & \multicolumn{2}{|c|}{ Atopic dermatitis } & 25 & 58 & 76 & 159 & 5.97 \\
\hline & \multicolumn{2}{|c|}{ Pityriasis alba } & 18 & 44 & 58 & 120 & 4.50 \\
\hline & \multicolumn{2}{|c|}{ Seborrheic dermatitis } & 9 & 38 & 25 & 72 & 2.70 \\
\hline & \multicolumn{2}{|c|}{ Contact dermatitis and eczema } & 16 & 55 & 47 & 118 & 4.43 \\
\hline & \multicolumn{2}{|c|}{ Perianal dermatitis } & 10 & 11 & 4 & 25 & 0.94 \\
\hline & \multicolumn{2}{|c|}{ Diaper dermatitis } & 28 & 5 & 0 & 33 & 1.24 \\
\hline \multirow{2}{*}{$\begin{array}{l}\text { Nutritional } \\
\text { disorder }\end{array}$} & \multicolumn{2}{|c|}{ phrynoderma } & 0 & 22 & 15 & 37 & 1.39 \\
\hline & \multicolumn{2}{|c|}{ Cheilitis/gingivitis/stomatitis } & 0 & 10 & 12 & 22 & 0.82 \\
\hline \multirow{6}{*}{$\begin{array}{l}\text { Pigmentary } \\
\text { disorders }\end{array}$} & \multicolumn{2}{|c|}{ Vitiligo } & 14 & 36 & 66 & 116 & 4.36 \\
\hline & \multirow{2}{*}{ Nevus } & Congenital & 5 & 22 & 34 & 61 & 2.29 \\
\hline & & Nevus achromicus & 7 & 5 & 14 & 26 & 0.97 \\
\hline & \multicolumn{2}{|c|}{ Ashy dermatoses } & 0 & 0 & 3 & 3 & 0.11 \\
\hline & \multicolumn{2}{|c|}{ Mongolian spots } & 13 & 0 & 0 & 13 & 0.49 \\
\hline & \multicolumn{2}{|l|}{ Albinism } & 2 & 1 & 0 & 3 & 0.11 \\
\hline & \multicolumn{2}{|c|}{ Pityriasis rosea } & 0 & 4 & 30 & 34 & 1.28 \\
\hline & \multicolumn{2}{|c|}{ Lichen planus } & 0 & 5 & 10 & 15 & 0.56 \\
\hline & \multicolumn{2}{|c|}{ Lichen nitidus } & 0 & 17 & 22 & 39 & 1.46 \\
\hline Papulosquamous & \multicolumn{2}{|c|}{ Pityriasis rubra pilaris } & 0 & 8 & 16 & 24 & 0.90 \\
\hline & \multicolumn{2}{|c|}{ Lichen striatus } & 0 & 5 & 8 & 13 & 0.49 \\
\hline & \multicolumn{2}{|c|}{ Lichen spinulosus } & 0 & 0 & 8 & 8 & 0.30 \\
\hline & \multicolumn{2}{|c|}{ Psoriasis } & 0 & 4 & 18 & 22 & 0.83 \\
\hline Keratinization & \multicolumn{2}{|l|}{ Icthyosis } & 6 & 12 & 14 & 26 & 0.98 \\
\hline disorder & Keratodern & & 0 & 5 & 8 & 13 & 0.49 \\
\hline Bullous disorder & & & 0 & 1 & 2 & 3 & 0.11 \\
\hline & Sweat & Miliaria & 4 & 15 & 22 & 41 & 1.54 \\
\hline & & Milia & 2 & 0 & 5 & 7 & 0.26 \\
\hline & sebaceous & Acne & 5 & 0 & 22 & 27 & 1.01 \\
\hline & glands & Fordyce spots & 0 & 2 & 1 & 3 & 0.11 \\
\hline & & Diffuse hair fall & 0 & 2 & 22 & 24 & 0.90 \\
\hline Appendageal & & Alopecia & 3 & 5 & 32 & 40 & 1.50 \\
\hline disorder & Hair & Trichotillomania & 0 & 1 & 5 & 6 & 0.23 \\
\hline & & $\begin{array}{l}\text { Sparse or congenital } \\
\text { absence of hair }\end{array}$ & 1 & 3 & 6 & 10 & 0.37 \\
\hline & & Nail psoriasis & 0 & 0 & 2 & 2 & 0.07 \\
\hline & Nail & Nail lichen planus & 0 & 0 & 1 & 1 & 0.03 \\
\hline & & others & 1 & 1 & 4 & 6 & 0.23 \\
\hline Drug reactions an & urticaria & & 2 & 13 & 15 & 30 & 1.12 \\
\hline & Hemangior & & 5 & 2 & 2 & 9 & 0.34 \\
\hline & Genoderm & toses & 2 & 3 & 8 & 13 & 0.49 \\
\hline $\begin{array}{l}\text { Vascular and } \\
\text { miscellaneous }\end{array}$ & Connective & tissue disorder & 0 & 0 & 3 & 3 & 0.11 \\
\hline & $\begin{array}{l}\text { Child abus } \\
\text { transmitted }\end{array}$ & $\begin{array}{l}\text { and sexually } \\
\text { diseases }\end{array}$ & 0 & 2 & 8 & 10 & 0.37 \\
\hline
\end{tabular}

Among other infections, bacterial was the most common with impetigo the commonest contributing $27.94 \%$ in 102 children (Table 1).

Varicella (Figure 1) was most common among viral infection contributing to $6.8 \%$ in 25 children and dermatophyte infection was the most common among fungal infection contributing $22.19 \%$ in 81 children of the study.
Childhood leprosy and cutaneous tuberculosis were found to contribute $0.56 \%$ of the study and $4.11 \%$ among infectious disorder.

Most common non-infectious dermatoses were atopic dermatitis including pityriasis alba $(10.49 \%)$ followed by contact dermatitis $(4.43 \%)$, seborrheic dermatitis $(2.71 \%)$. 


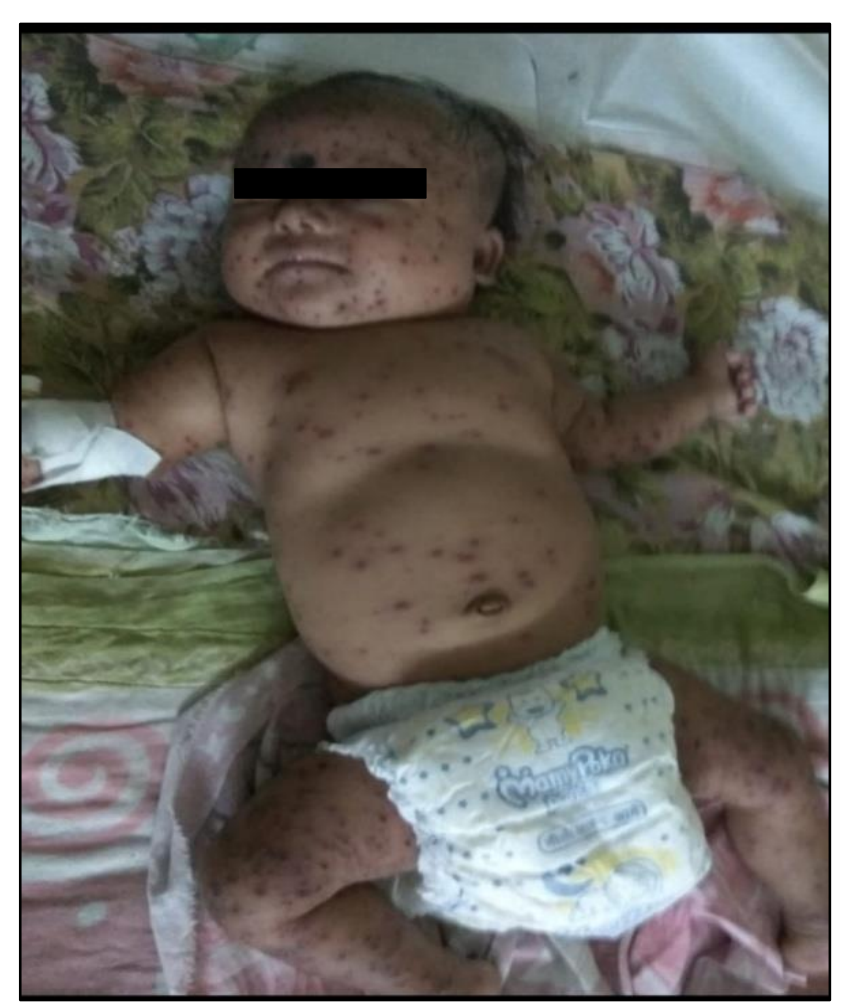

Figure 1: Infantile varicella.

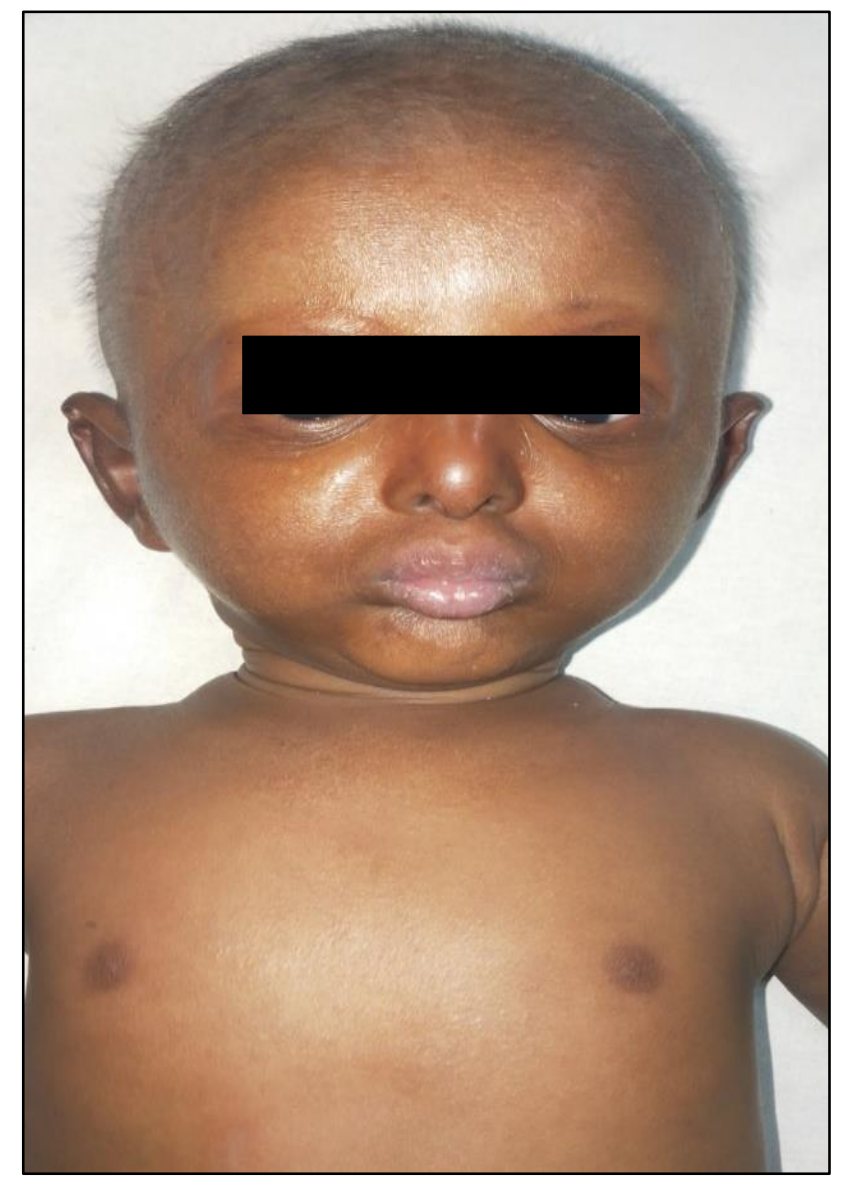

Figure 2: Ectodermal dysplasia in a 4-monthold infant.
Among pigmentary disorder vitiligo was most common with overall $4.35 \%$ in 116 children.

Genodermatoses such as ectodermal dysplasia (Figure 2), cutis laxa and neurofibromatosis were found in $0.49 \%$ of the total cutaneous dermatoses.

Authors also observed that seborrheic dermatitis, atopic dermatitis, cutaneous candidiasis, scabies and tinea capitis were more common in age group 1 month to 1 year. In pre-school age group ( $>1$ to 6 years) scabies, impetigo, pyoderma, molluscum contagiosum and atopic dermatitis were common. While in school going children (7 to 14 years) scabies, molluscum contagiosum, phrynoderma, pyoderma and pityriasis alba were most common diseases in order of incidence.

\section{DISCUSSION}

Cutaneous dermatoses are a major health problem in the pediatric population and are associated with significant morbidity. Skin diseases in pediatric age group can be transitory or chronic and recurrent.

The prevalence of pediatric dermatoses in the present study is $9.5 \%$, whereas in various parts of India, it has ranged from $8.7 \%$ to $35 \%$ in school-based surveys. ${ }^{4}$

In the study, majority of the patients were in school going age group 1202 (46.58\%) followed by preschool children $989(38.32 \%)$ and infants $390(15.11 \%)$ respectively. Similar observation was made by Sacchidanand et al observed 5-11 years is the common age group followed by adolescents with $33.21 \%$ and $29.81 \%$, respectively. ${ }^{6}$

Dermatoses was found to be more in male children 1570 (60.83\%) than in females 1011 (39.17\%) in the present study with male to female ratio of 1.5:1. Similar observation was made by Sharma et al, Females outnumbered males in very few studies. ${ }^{7}$

In this study, majority of dermatoses belonged to infestations and infections group 1421 (53.39\%). Sacchidanand et al, Negi et al, Sharma et al, Mendiratta et al, Bhatia et al and Ghosh et al have reported infections and infestations occurring in the range of $35.6-85 \%{ }^{6-10} \mathrm{In}$ all these studies, whether institution based or community based, the infections and infestations were the main group of dermatoses.

Of the total pediatric dermatoses, infestations (1056 patients; 39.68\%) were the most common dermatoses, followed by eczematous disorder in 527 children (19.80\%), infection in 365 children (13.71\%).

Among 365 children with infections, bacterial infections (178 children, $48.77 \%$ ) were the most common followed by fungal infections (115 children, 31.58\%) and viral infections (72 children; 19.73\%). Similar pattern has been observed by Sayal et al. ${ }^{11}$ 
Of the infestations, scabies alone constituted the majority, making $24.23 \%$ of the total dermatoses which is higher than the previous studies done. Sacchidanand et al in their study found that the incidence of scabies was $6.97 \% .^{6}$ The incidence of scabies had varied from $5.1 \%$ to $22.4 \%$. In studies done by Sharma et al, Mendiratta et al, Bhatia et al, and Negi et al, in their study pointed out that the prevalence of scabies in general population of rural communities in India is about $5 \% .^{8,9,12}$

The higher prevalence of scabies in the study might be because of lack of hygienic practices and congested environment.

Pediculosis capitis was the next most common infestation following scabies constituting $16.62 \%$ in this study.

Fungal infections of the skin constituted $31.58 \%$ of the total infections and $4.32 \%$ of total dermatoses. Dermatophytic infections were the most common among these infections making up to $22.19 \%$ of the infections.

Bacterial infections constituted $48.73 \%$ of the total infections and $6.69 \%$ of total pediatric dermatoses.

Impetigo was the most common bacterial infection with $57.30 \%$ (102 children) of total bacterial infections (178 children) followed by pyoderma (60 children, $33.70 \%$ ), cutaneous tuberculosis (9 children, 5.05\%), Hansen's disease (6 children, $3.37 \%$ ). A single case of proved congenital syphilis was observed in the study. Pyodermas were the single most common dermatoses found out by Bhatia and Ghosh et al. ${ }^{9}$

The viral infections constituted $19.73 \%$ of the total infections and $2.70 \%$ of total dermatoses of this study. Varicella was the most common viral disease constituting $47 \%$ of these viral infections and $1.2 \%$ of total dermatoses followed by molluscum contagiosum constituting $25 \%$ of these viral infections and $0.6 \%$ of total dermatoses followed by viral warts which constituted $23.61 \%$ of viral infections and $0.6 \%$ of total dermatoses.

Sirisha et al, in their study observed that incidence of molluscum contagiosum was $1.16 \%$ in children aged 1 to $15 .^{13}$

The incidence of Varicella was $1.2 \%$ in this study whereas in the study done by Sirisha et al it is reported as he most common viral infection $(1.83 \%)$.

Eczema was the second common group of dermatoses in the study constituting $39.68 \%$ of total dermatoses. The incidence rate of eczema in the study by Sacchidanand et al was $20.66 \%$, whereas in Karthikeyan et al study, it was $8.6 \%$ and in Sirisha et al study it is $19.17 \% .6,13,14$

Of the eczema group, atopic dermatitis was the commonest and constituted $30.17 \%$ of eczematous disorders, followed by pityriasis alba $(22.77 \%)$, contact dermatitis (22.39\%), seborrheic dermatitis (13.66\%), diaper dermatitis $(6.26 \%)$, perianal dermatitis $(4.74 \%)$.

Sacchidanand et al, reported atopic dermatitis as the most common eczematous dermatitis which constituted $6.12 \% .^{6}$ Few other studies also showed atopic dermatitis as the most common endogenous eczema which ranges from $3 \%$ to $28 \%$.

Hypersensitivity and drug reactions (Figure 3) constituted $1.12 \%$ of all dermatoses.

In a study by Karthikeyan et al, urticaria constituted $2.5 \%$ of all cases. Insect bite allergy (papular urticaria) contributed to $1.38 \%$ of the study population. ${ }^{14}$ Ghosh et al observed a frequency of $4 \%$ in their study. ${ }^{10}$

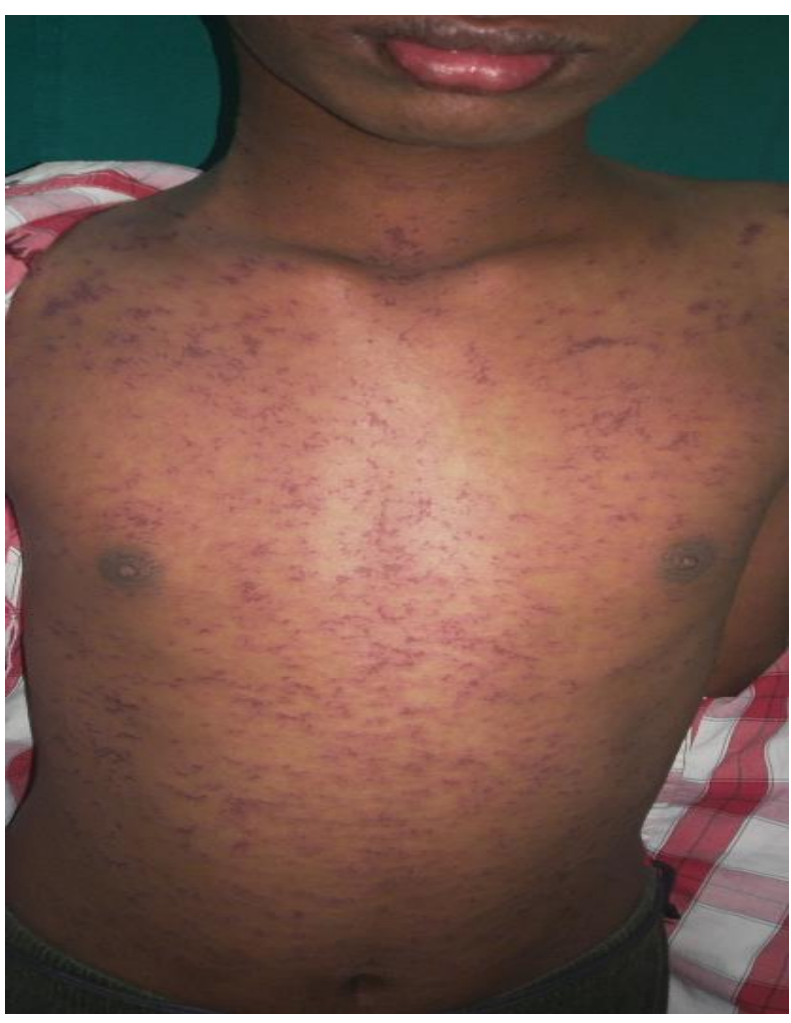

Figure 3: Maculopapular rash in a child.

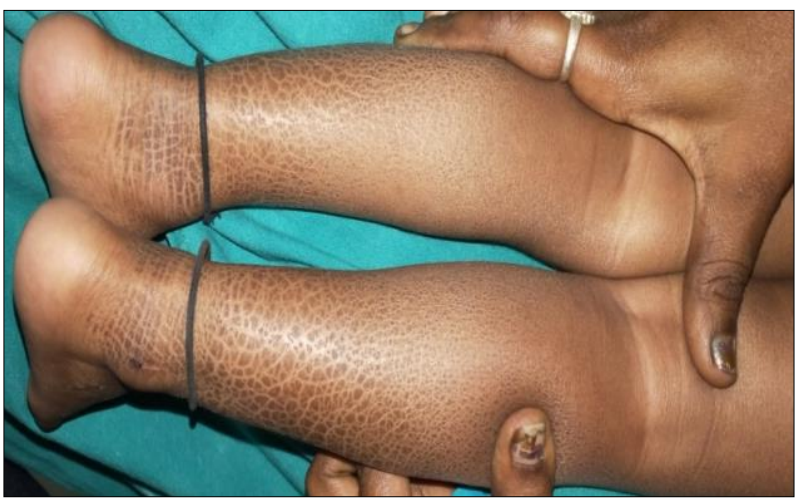

Figure 4: Icthyosis vulgaris in an infant. 


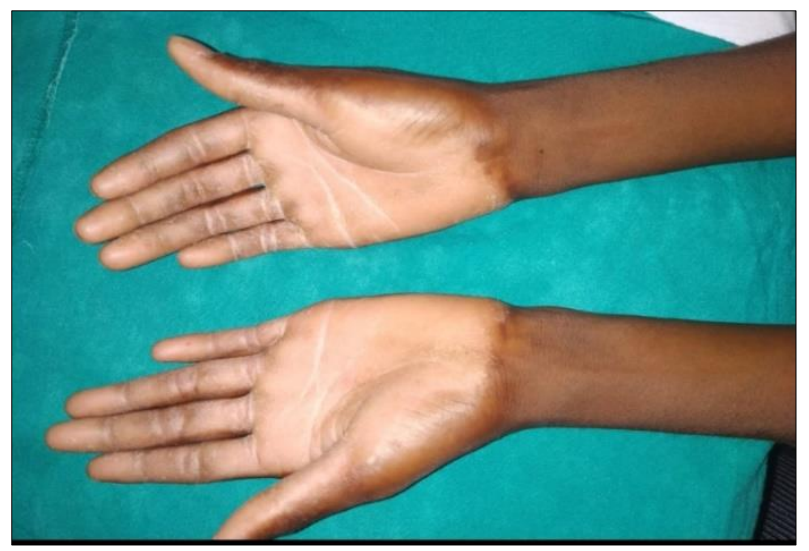

Figure 5: Palmar keratoderma.

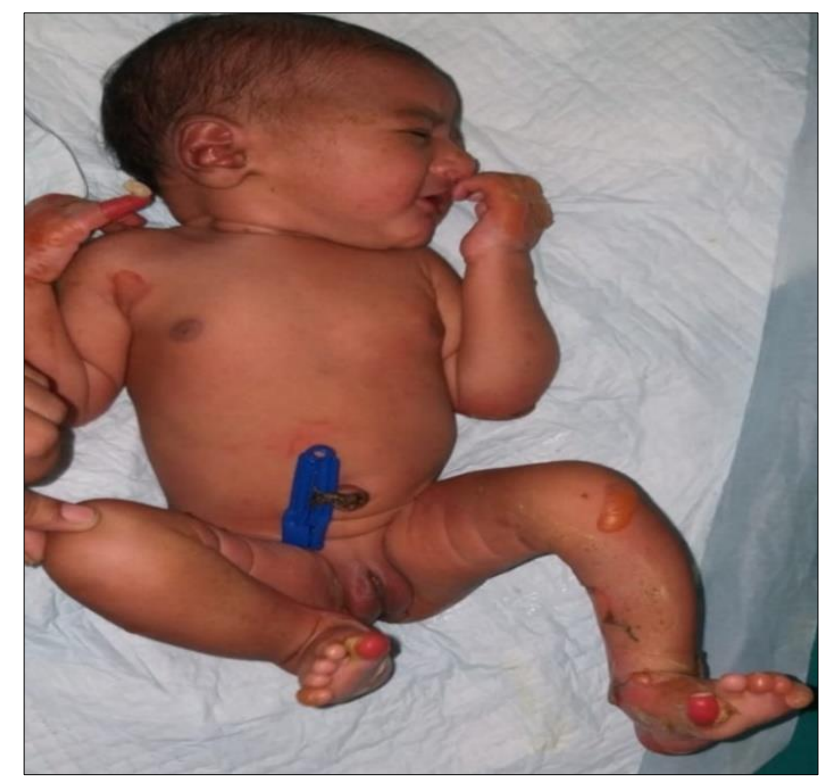

Figure 6: Epidermolysis bullosa simplex in an infant.

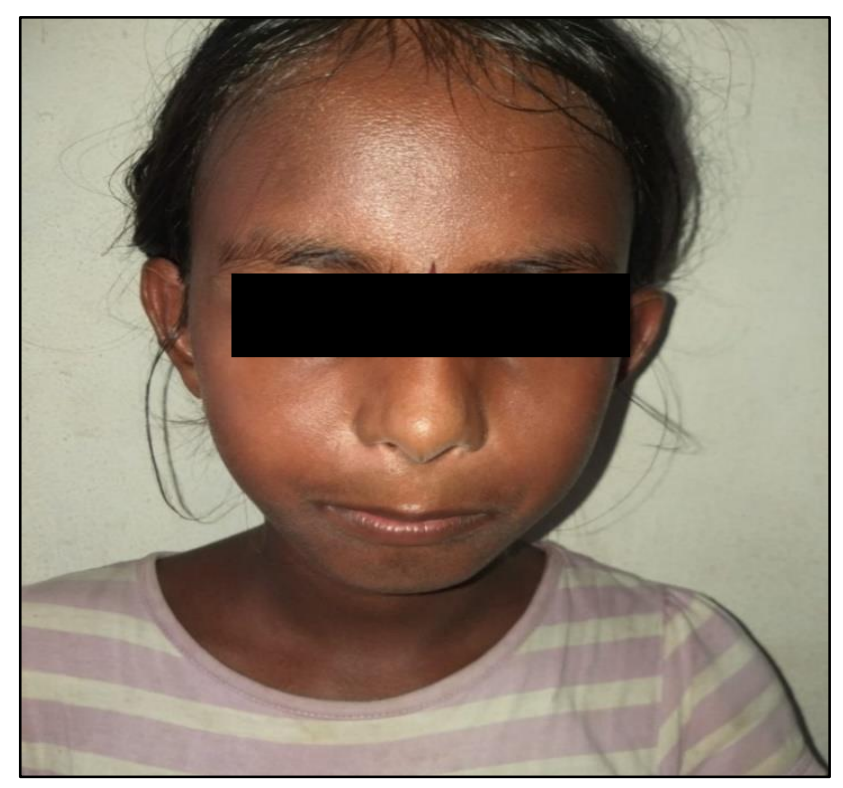

Figure 7: Childhood systemic sclerosis.

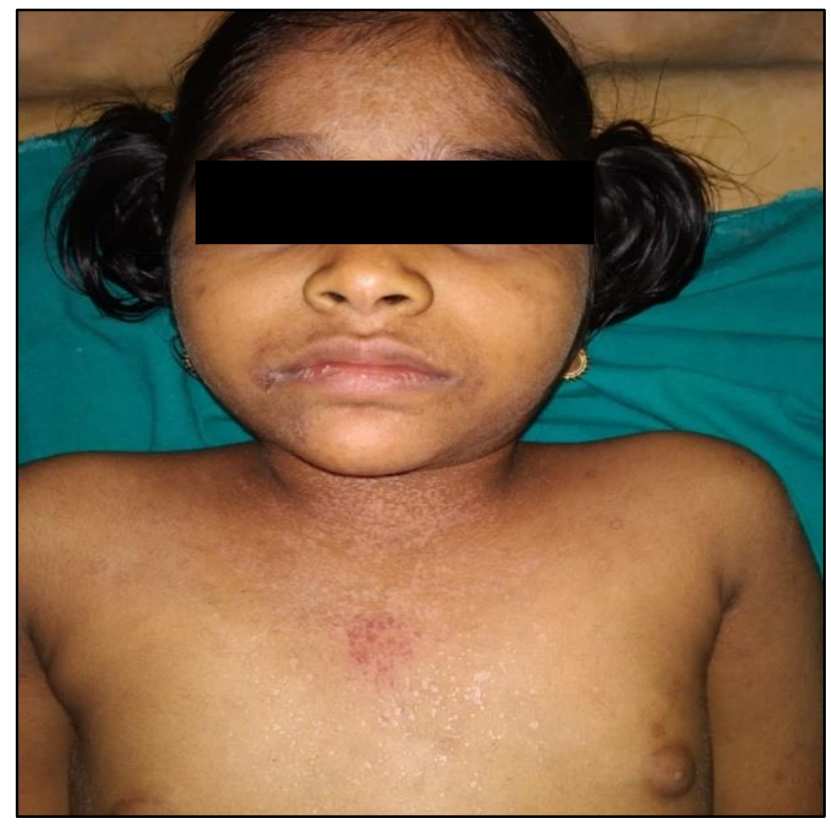

Figure 8: Epidermodysplasia verruciformis with tinea versicolar like lesions and plane warts.

Sweat gland disorders constituted $2.9 \%$ of dermatoses during this study period prevalence rate of $1.2 \%$ is seen for miliaria in a study by Reddy et al. ${ }^{15}$ In the study done by Karthikeyan et al, the prevalence of miliaria was $4.1 \% .{ }^{14}$ In the present study it was $1.5 \%$.

Pigmentary disorders constituted $8.3 \%$ of total dermatoses in this study. Vitiligo was the most common constituting $4.36 \%$. Sacchidanand et al, reported that pigmentary disorders constituted $5.81 \%$ and Sirisha et al reported $2.89 \% .^{6,13}$

Among 45 keratinization disorders observed, Icthyosis (Figure 4) was seen in 32 children constituting $1.2 \%$ of total dermatoses and keratoderma (Figure 5) in children with $0.4 \% .^{13}$

Reddy et al observed the prevalence of Icthyosis in $0.8 \% .^{15}$

Hair and scalp disorders constituted $3.00 \%$ of the total dermatoses. Alopecia areata (1.5\%) was the most common hair and scalp disorder followed by diffuse hair loss $(0.9 \%)$ congenital absence of hair or sparse hair $(0.3 \%)$ (Figure 2 ) and trichotillomania $(0.2 \%)$. Vora et al observed alopecia in $0.07 \%$ of children. ${ }^{16}$

Papulosquamous disorders were noted in $5.8 \%$ of the cases during this study period. Prevalence of papulosquamous disorders in the study of Sirisha et al was $6.32 \%$ and Medasani et al was $0.92 \% .^{13,17}$ Lichen nitidus was the most common dermatoses and constituted about $1.46 \%$ of the total dermatoses. Lichen planus constituted about $1.2 \%$ of the total dermatoses Psoriasis constituted about $0.8 \%$ of the total dermatoses. 
Karthikeyan et al reported prevalence of psoriasis as $1.4 \% . .^{14}$

Vesiculobullous disorders constituted $0.11 \%$ of total dermatoses with 3 cases of different types epidermolysis bullosa (Figure 6). According to Medasani et al, the prevalence rate of epidermolysis bullosa simplex was $0.46 \% .^{17}$

Connective tissue disorders (CTD) were noted in 3 children, 2 systemic lupus erythematosus and 1 systemic sclerosis (Figure 7) constituting $0.11 \%$ of total dermatoses. The prevalence of CTD is $0.37 \%$ in a study done by Pelkonan et al, and child abuse and sexually transmitted infections were observed in 10 female children constituting $0.37 \% .^{18}$

\section{CONCLUSION}

The study reinforces features of tropical pediatric dermatology especially high prevalence of infections and infestations in school children (5-12 years) which highlights the need of proper counseling of caretaker regarding skin hygiene and establishment of specialized pediatric dermatology clinics.

\section{ACKNOWLEDGEMENTS}

Authors would like to thank Dr. Rudra Priya, Dr. Sravani Gedela and Dr. Prashanthi Vellanki department of Dermatology, Venereology, Leprology, Rangaraya Medical College, Kakinada, for helping us in data collection and analysis.

\section{Funding: No funding sources}

Conflict of interest: None declared

Ethical approval: The study was approved by the institutional ethics committee

\section{REFERENCES}

1. Park K. Preventive medicine in obstetrics, pediatrics, and geriatrics, In: Park's Textbook of Preventive and Social Medicine, $17^{\text {th }}$ ed. Park K, Jabalpur: Banarsidas Bhanot Publishers; 2002: 359411.

2. Hayden GF. Skin diseases encountered in a pediatric clinic. Am J Dis Child. 1985;139:36-8.

3. Thappa DM. Common skin problems in children. Indian J Pediatr. 2002;69:701-6.

4. Sayal SK, Bal AS, Gupta CM. Pattern of skin diseases in pediatric age group and adolescents. Indian J Dermatol Venereol Leprol. 1998;64:117-9.

5. Sharma RC, Mendiratta V. Clinical profile of cutaneous infections and infestations in pediatric age group. Indian J Dermatol. 1999;44:174-8.
6. Sacchidanand S, Sahana MS, Asha GS, Shilpa K. Pattern of pediatric dermatoses at a referral centre. Indian J Pediatr. 2014;81:375-80.

7. Sharma S, Bassi R, Sodhi MK. Epidemiology of dermatoses in children and adolescents in Punjab, India. J Pak Assoc Dermatol. 2012;22:224-30.

8. Sharma RC, Mendiratta RC. Clinical profile of cutaneous infections and infestations in pediatric age group. Indian J Dermatol. 1999;44:174-8.

9. Bhatia V. Extent and pattern of pediatric dermatoses in central India. Indian J Dermatol Venereol Lepro1. 1997;63:22-5.

10. Ghosh SK, Saha DK, Roy AK. A clinico aetiological study of dermatoses in pediatric age group. Indian J Dermatol. 1995;40:29-31.

11. Sayal SK, Bal AS, Gupta CM. Pattern of skin diseases in paediatric age group and adolescents. Indian J Dermatol Venereol Leprol. 1997;64(3):1179.

12. Negi KS, Kandpal SD, Prasad D. Pattern of skin diseases in children in Garhwal region of Uttar Pradesh. Indian Pediatr. 2001;38:77-80.

13. Sirisha N. Pattern of pediatric dermatoses in tertiary care hospital, Government Medical College, Kadapa. Indian J Applied Res. 2019;10(9):39-40.

14. Karthikeyan K, Thappa DM, Jeevankumar B. Pattern of pediatric dermatoses in a referral centre in South India. In Pediatr. 2004;41:373-7.

15. Reddy VS, Anoop T, Ajayakumar S, Bindurani S, Rajiv S, Bifi J. Study of clinical spectrum of pediatric dermatoses in patients attending a Tertiary Care Center in North Kerala. Indian J Paediatr Dermatol. 2016;17:267-72.

16. Vora R, Bodiwala N, Patel S. Prevalence of various dermatoses in school children of Anand district. Natl J Community Med. 2012;3:100-3.

17. Medasani V, Oudeacoumar P, Chitralekhya R, Misra SK. Prevalence of paediatric dermatoses among patients attending dermatology outpatient department in a tertiary care hospital in Puducherry. Int J Res Dermatol. 2018;4:368-75.

18. Pelkonan PM, Jalanko HJ, Lantto RK, Makela AL, Pietikainen MA, Savolainen HA, et al. Incidence of systemic connective diseases in children: a nationwide prospective study in finland. $\mathbf{J}$ Rheumatol.1994;21(11):2143-6.

Cite this article as: Bonthu I, Purushothaman S, Vukkadala ND. Clinico-etiological study of pediatric dermatoses in tertiary health care hospital in East-coast Andhra Pradesh, India. Int J Res Dermatol 2020;6:456-62. 